\title{
Ouabain Induces DNA Damage in Human Osteosarcoma U-2 OS Cells and Alters the Expression of DNA Damage and DNA Repair-associated Proteins
}

\author{
JIUN-LONG YANG ${ }^{1 *}$, MEI-DUE YANG ${ }^{2 *}$, JAW-CHYUN CHEN $^{3}$, KUNG-WEN LU $^{4}$, \\ YI-PING HUANG ${ }^{5}$, SHU-FEN PENG ${ }^{6,7}$, FU-SHIN CHUEH ${ }^{8}, \mathrm{KUO}^{-C H I N G}$ LIU $^{9}$, \\ TZU-SHUN LIN ${ }^{1,10}$, PO-YUAN CHEN ${ }^{6 \#}$ and WEI-JEN CHEN ${ }^{11,12 \#}$ \\ ${ }^{1}$ Department of Nursing, Saint Mary's Junior College of Medicine, Nursing and Management, Yilan, Taiwan, R.O.C.; \\ ${ }^{2}$ Department of Surgery, China Medical University Hospital, Taichung, Taiwan, R.O.C.; \\ ${ }^{3}$ Department of Medicinal Botany and Health Applications, Da-Yeh University, Changhua, Taiwan, R.O.C.; \\ ${ }^{4}$ College of Chinese Medicine, School of Post-Baccalaureate Chinese Medicine, \\ China Medical University, Taichung, Taiwan, R.O.C., \\ ${ }^{5}$ Department of Physiology, School of Medicine, China Medical University, Taichung, Taiwan, R.O.C.; \\ ${ }^{6}$ Department of Biological Science and Technology, China Medical University, Taichung, Taiwan, R.O.C.; \\ ${ }^{7}$ Department of Medical Research, China Medical University Hospital, Taichung, Taiwan, R.O.C.; \\ ${ }^{8}$ Department of Food Nutrition and Health Biotechnology, Asia University, Taichung, Taiwan, R.O.C.; \\ ${ }^{9}$ Department of Medical Laboratory Science and Biotechnology, China Medical University, Taichung, Taiwan, R.O.C.; \\ ${ }^{10}$ Department of Pharmacy, Saint Mary's Hospital Luodong, Yilan, Taiwan, R.O.C.; \\ ${ }^{11}$ Department of Orthopedics, Chang Bing Show-Chwan Memorial Hospital, Changhua, Taiwan, R.O.C.; \\ ${ }^{12}$ Department of Orthopedics, Show-Chwan Memorial Hospital, Changhua, Taiwan, R.O.C.
}

\begin{abstract}
Background/Aim: Ouabain, isolated from natural plants, exhibits anticancer activities; however, no report has presented its mechanism of DNA damage induction in human osteosarcoma cancer cells in vitro. The aim of this study was to investigate whether ouabain induces DNA damage and repair, accompanied with molecular pathways in human osteosarcoma cancer U-2 OS cells in vitro. Materials and
\end{abstract}

This article is freely accessible online.

\footnotetext{
*,\#These Authors contributed equally to this study.

Correspondence to: Po-Yuan Chen, Ph.D., Department of Biological Science and Technology, China Medical University, No. 100, Section 1, Jingmao Road, Beitun District, Taichung, Taiwan, R.O.C. Tel: +886422053366 ext. 2525 , Fax: +886422053764 , e-mail: pychen@mail.cmu.edu.tw; and Wei-Jen Chen, Dr., Department of Orthopedics, Show Chwan Memorial Hospital, No. 542, Section 1, Chung-Shan Road, Changhua, Taiwan, R.O.C. Tel: +886975617171, e-mail: weijen128@yahoo.com.tw
}

Key Words: Ouabain, human osteosarcoma cancer U-2 OS cells, DNA damage, DNA condensation, DNA repair.
Methods: The percentage of viable cell number was measured by flow cytometric assay; DNA damage was assayed by DAPI staining, comet assay, and agarose gel electrophoresis. DNA damage and repair associated protein expressions were assayed by western blotting assays. Results: Ouabain reduced total cell viability, induced chromatin condensation, DNA fragmentation, and DNA damage in U-2 OS cells. Ouabain increased p-ATM ${ }^{\text {Ser1981, }}$ $p-A T R^{\operatorname{Ser} 428}$, and $p 53$ at 2.5-10 $\mu \mathrm{M}$, increased $p-p 53^{\text {Ser15 }}$ at $10 \mu \mathrm{M}$; however, it decreased p-MDM2 $2^{\text {Ser166 }}$ at 2.5-10 $\mu \mathrm{M}$. Ouabain increased p-H2A.X ${ }^{\text {Ser139 }}, M D C-1$, and PARP at 2.5 $10 \mu M$ and BRCA1 at 5-10 $\mu M$; however, it decreased DNA$P K$ and MGMT at 2.5-10 $\mu M$ in U-2 OS cells at $48 \mathrm{~h}$ treatment. Ouabain promoted expression and nuclear

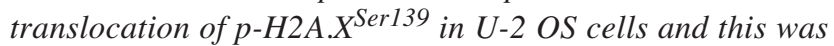
confirmed by confocal laser microscopy. Conclusion: Ouabain reduced total viable cell number through triggering DNA damage and altering the protein expression of DNA damage and repair system in U-2 OS cells in vitro.

Osteosarcoma (OS) originates from long bones, including the humerus, femur, and tibia $(1,2)$ and it is the most frequent type of malignant bone cancer. OS contributes to cancer- 
related mortality in adolescents $(3,4)$ and accounts for $~ 5 \%$ of cases of childhood cancer $(2,5,6)$. Patients with osteosarcoma often have also a metastatic or recurrent disease, leading to a lower percentage of survival (7). Currently, the treatment of OS includes surgery, radiotherapy, and multiagent chemotherapy or a combination of chemotherapy, radiation therapy, and surgery, which have been shown to improve patient survival, which is still unsatisfactory (8-10). Therefore, developing effective and safe compounds for improving the survival rate of OS patients is urgent, and many studies are focusing on finding new compounds from natural products.

Agents and anticancer drugs inducing DNA single-strand break (SSB) or double-strand break (DSB) lesions may lead to genomic instability and cause cancer development. Etoposide induces double-strand damage of cancer cells by acting as an inhibitor of DNA topoisomerase II (11). Temozolomide, the first-line monotherapeutic agent for glioblastoma patients (12), exerts its cytotoxic effect by the induction of $\mathrm{O}^{6}$-methylguanine and leads to DAN damage, including the formation of DNA double-strand breaks (DSB) and cell death (13). Tobacco smoke contains over 60 documented cancer-causing agents and some of these agents have been documented to induce DNA damage and mutations in human cells (14). Eukaryotic cells exhibit a network of biochemical pathways to sense, signal, and repair the DNA damage for regulating DNA damage response $(15,16)$. After being exposed to DNA damage agents, cells can repair DNA damage and remain alive. Otherwise, this may lead to cell death (17). Numerous anticancer drugs have been obtained from natural products. Therefore, these products induce DNA damage or affect DNA repair systems of cancer cells and this may play important roles in their anticancer activities.

Ouabain, a cardiotonic steroid, is derived from the Strophanthus gratus and Acokanthera schimperi and acts like a hormone $(18,19)$ that regulates cell adhesion $(20)$. Ouabain is also secreted endogenously by the adrenal glands (21) and exerts $\mathrm{Na}^{+} / \mathrm{K}^{+}$-ATPase binding activity (22). Besides, ouabain regulates blood pressure and $\mathrm{Na}^{+}$homeostasis $(23$, 24) and it has been also used for the treatment of heart failure and atrial fibrillation (25). Recently, it was shown that ouabain represents an attractive agent due to improved survival rate of gastric cancer patients $(26,27)$ and it exerts various biological functions in human cancer cells. It suppressed proliferation of breast cancer, including MCF-7 and MDA-MB-231 cells (28), induced TRAIL-mediated cell death in human lung cancer cells and prostate DU 145 cancer cells $(29,30)$, and triggered cell apoptosis in Jurkat cells (human acute T-cell lymphoblastic leukemia cells) (31). Besides, ouabain suppressed human renal cancer OS-RC-2 cell proliferation by targeting to the NKA $\alpha 3$ isoform (32). Furthermore, ouabain reduced IL-2 secretion and resulted in a decrease in regulatory $\mathrm{T}$ cell numbers in mice (33).
Currently, there are several reports regarding ouabain decreasing total viable cell number via inducing cell apoptosis in human osteosarcoma U-2 OS cells. However, the effects and possible signaling pathways associated with the expression of DNA damage and repair-associated proteins which were induced in human osteosarcoma cancer cells are still unclear. Therefore, herein, its effects on U-2 OS human osteosarcoma cancer cells were investigated. It was found that ouabain induced DNA damage and suppressed DNA repair associated protein expressions in U2 OS cells in vitro.

\section{Materials and Methods}

Chemicals and reagents. Ouabain, dimethyl sulfoxide (DMSO), propidium iodide (PI), phosphate buffered saline (PBS), and trypsinEDTA used in this study were obtained from Sigma-Aldrich Corp. (St. Louis, MO, USA). McCoy's 5A medium, fetal bovine serum (FBS), L-glutamine, penicillin, and streptomycin were obtained from Invitrogen Life Technologies (Carlsbad, CA, USA). Anti-pATMSer1981, -PARP, and -p-H2A.XSer139 were obtained from GeneTex Inc. (Irvine, CA, USA). Anti-p-ATR ${ }^{\mathrm{Ser} 428}$, -pMDM2Ser166, -p-p53Ser15, and -BRCA1 were obtained from Cell Signaling Technology (Danvers, MA, USA). Anti-MGMT, -p53, and $-\beta$-actin were obtained from Sigma-Aldrich Corp.. Anti-DNA-PK was purchased from Calbiochem (San Diego, CA, USA). AntiMDC1 was purchased from Millipore (Billerica, MA, USA). The anti-mouse IgG was obtained from Amersham Pharmacia Biotech, Inc (Piscataway, NJ, USA).

Cell line and cell culture. The human osteosarcoma cancer U-2 OS cell line was purchased from the Food Industry Research and Development Institute (Hsinchu, Taiwan). Cells were cultured in 90\% McCoy's 5A medium supplemented $2 \mathrm{mM} \mathrm{L-glutamine,} 10 \%$ FBS, and antibiotics (100 Units/ml penicillin and $100 \mu \mathrm{g} / \mathrm{ml}$ streptomycin) in $75 \mathrm{~cm}^{2}$ tissue culture flasks. Cells were cultured in a humidified incubator at $37^{\circ} \mathrm{C}$ and $5 \% \mathrm{CO}_{2}$ atmosphere (34).

Cell viability. U-2 OS cells were seeded at $1.6 \times 10^{5}$ cells/well in $12-$ well plates for $24 \mathrm{~h}$ and then treated with $0,2.5,5$, and $10 \mu \mathrm{M}$ of ouabain for $48 \mathrm{~h}$. After incubation, all cells from each well were harvested and re-suspended in PBS containing $5 \mu \mathrm{g} / \mathrm{ml}$ of PI for measuring the percentage of cell viability by using flow cytometer, as cited previously (34).

4,6-diamidino-2-phenylindole dihydrochloride (DAPI) staining. U-2 OS cells were grown at $1.6 \times 10^{5}$ cells/well in 12-well plate for $24 \mathrm{~h}$ and treated with $0,2.5,5$, and $10 \mu \mathrm{M}$ of ouabain for $48 \mathrm{~h}$. At the end of incubation, $3.7 \%$ paraformaldehyde (v/v) in PBS was used to fix cells for $15 \mathrm{~min}$, followed by being permeabilized with $0.1 \%$ Triton $\mathrm{X}-100$ in PBS for $5 \mathrm{~min}$, and stained with DAPI solution $(2 \mu \mathrm{g} / \mathrm{ml})$ for $10 \mathrm{~min}$. All cells in each well were examined and photographed using a fluorescence microscope at 100×, as described previously (35).

Comet assay. The comet assay was used to determine the phenomenon of DNA damage in U-2 OS cells after exposed to ouabain, as described previously (36). U-2 OS cells $\left(1.6 \times 10^{5}\right.$ cells/well) were incubated with $0,2.5,5$, and $10 \mu \mathrm{M}$ of ouabain or $\mathrm{H}_{2} \mathrm{O}_{2}$ (as a positive control) for $48 \mathrm{~h}$. All cells from each sample 
were examined for DNA damage by using comet assay (single-cell electrophoresis). The comets were randomly captured at a constant depth of the gel, and comet tail length was measured and quantified by using the Tri Tek Comet Score ${ }^{\mathrm{TM}}$ software image analysis system (TriTek Corp, Sumerduck, VA, USA) as described previously (36).

DNA gel electrophoresis. U-2 OS cells $\left(2 \times 10^{6}\right.$ cells $)$ in $10-\mathrm{cm}$ dishes were exposed to $0,2.5,5$, and $10 \mu \mathrm{M}$ of ouabain for $48 \mathrm{~h}$. After treatment, cells were harvested from each treatment and lysed in ice-cold lysis buffer and then DNA was extracted. The resulting DNA was quantitated and electrophoresed on a $1.5 \%$ agarose gel, examined and photographed as previously described (37).

Western blotting. U-2 OS cells $\left(2 \times 10^{6}\right.$ cells $)$ in $10-\mathrm{cm}$ dishes were exposed to $0,2.5,5$, and $10 \mu \mathrm{M}$ of ouabain for $48 \mathrm{~h}$, and cells from each treatment were collected. The total cellular proteins from each sample were extracted by RIPA buffer [50 mM Tris-HCI (pH 7.4), $125 \mathrm{mM} \mathrm{NaCl}, 0.1 \%$ Triton X-100, and $5 \mathrm{mM}$ EDTA containing both $1 \%$ protease inhibitor and $1 \%$ phosphatase inhibitor mixture II] (Sigma-Aldrich Corp.) as described previously $(36,37)$ and extracted proteins were quantitated using BioRad assay kit (BSA as a protein standard) as described previously $(36,37)$. Each protein samples $(30 \mu \mathrm{g})$ were separated on sodium dodecyl sulfate polyacrylamide gel electrophoresis (SDS-PAGE) and transferred onto polyvinylidene difluoride (PVDF) membranes (Bio-Rad Laboratories, Richmond, CA, USA). The membranes were blocked with $2.5 \%$ BSA and probed with indicated primary antibodies: anti-

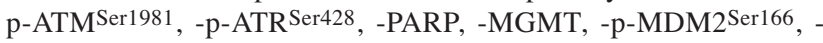
p53, -p-p53 Ser15, -p-H2A.X ${ }^{\text {Ser139, }}$,-BRCA1, -DNA-PK, -MDC1, and $-\beta$-actin $(1: 1,000)$. The appropriate secondary antibodies (goat antimouse IgG coupled to HRP used at a 1:5,000 dilution) and the bound antibodies were detected by Chemiluminescent HRP substrate (Millipore Corp.) and quantified by ImageJ software as described previously $(36,37)$

Confocal laser scanning microscopy. U-2 OS cells were grown on coverslips at $5 \times 10^{4}$ cells/slide and exposed to $0,2.5,5$, and $10 \mu \mathrm{M}$ of ouabain for $48 \mathrm{~h}$. After exposure, cells were fixed with $4 \%$ formaldehyde in PBS and were permeabilized by using $0.2 \%$ Triton$X 100$ in PBS for 15 min. Cells were washed and probed with anti-

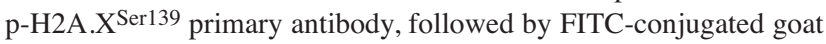
anti-mouse IgG (green fluorescence), and PI (red fluorescence) was used to stain the nucleus. After washed with PBS, all samples were examined and photographed under a Leica TCS SP2 Confocal Spectral Microscope as described previously $(36,37)$.

Statistical analysis. The data from each experiment are presented as the mean \pm standard deviation (S.D.) as indicated in the figures and were analyzed using one-way ANOVA. $p<0.05$ is considered as significant differences between the ouabain-treated and -untreated (control) groups.

\section{Results}

Ouabain decreased cell viability. U-2 OS cells were exposed to ouabain at a final concentration of $0,2.5,5$, and $10 \mu \mathrm{M}$ for $48 \mathrm{~h}$. All samples were collected and measured for total viable cell number (cell viability) by the PI exclusion method, and results are presented in Figure 1. Results

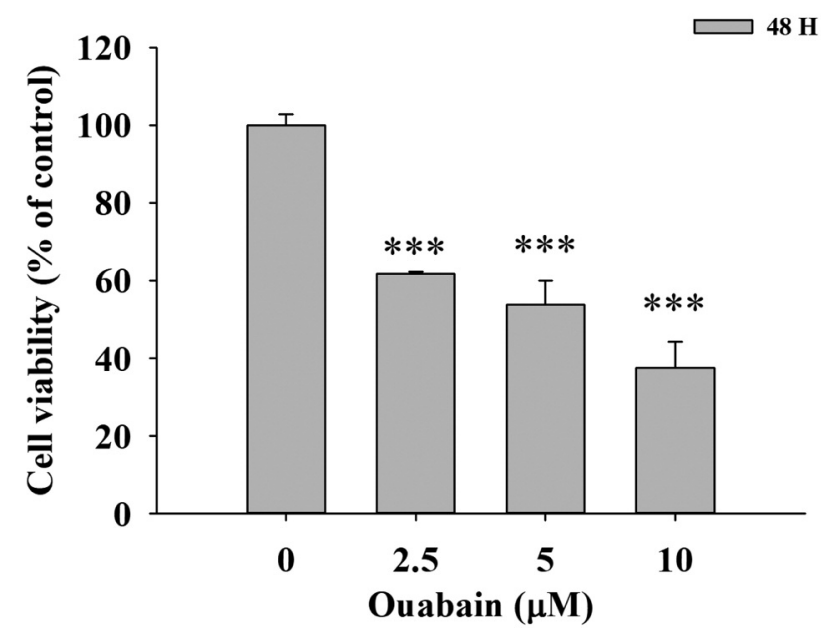

Figure 1. Ouabain decreased the percentage of viable cells in $U-2$ OS cells. Cells were incubated with 0, 2.5, 5, and $10 \mu \mathrm{M}$ of ouabain for 48 $h$ and were collected for measuring the percentage of viable cells by flow cytometry. Experiments were performed in triplicate as described in Materials and Methods. Data represent mean \pm S.D. $* p<0.05$ was significantly different between ouabain-treated and control groups.

indicated that increased concentrations $(2.5-10 \mu \mathrm{M})$ of ouabain led to decreasing total cell viability from 61.74 , 53.79 and $37.48 \%$, respectively, and these effects were observed in a dose-dependent manner (Figure 1).

Ouabain induced chromatin condensation. To understand whether ouabain reduced total cell viability via induction of chromatin condensation which is one of the character of cell apoptosis, U-2 OS cells were incubated with various concentrations $(0,2.5,5$, and $10 \mu \mathrm{M})$ of ouabain for $48 \mathrm{~h}$. Subsequently, cells were stained with DAPI solution, and the results are shown in Figure 2. Cells treated with ouabain showed a lighter staining (DAPI dyed; Figure 2A) and higher intensity of DAPI fluorescence (Figure 2B) than that of the control group in U-2 OS cells. Thus, results indicated that ouabain at $10 \mu \mathrm{M}$ for $48 \mathrm{~h}$ significantly induced chromatin condensation.

Ouabain induced DNA damage. For further exploring the reduction of cell viability of U-2 OS cells mediated by induction of DNA damage, cells were exposed to ouabain $(0$, $2.5,5$, and $10 \mu \mathrm{M}$ ) for $48 \mathrm{~h}$, collected, and measured using their comet tail by single-cell electrophoresis (comet assay). Ouabain at 5 and $10 \mu \mathrm{M}$ significantly increased comet tail length to that of control groups. The positive-control group $\left(\mathrm{H}_{2} \mathrm{O}_{2}\right)$ has the highest comet tail (Figure 3A). These observations indicated that ouabain induced DNA damage at $48 \mathrm{~h}$ treatment, and these effects are dose-dependent in U-2 OS cells (Figure 3B). 

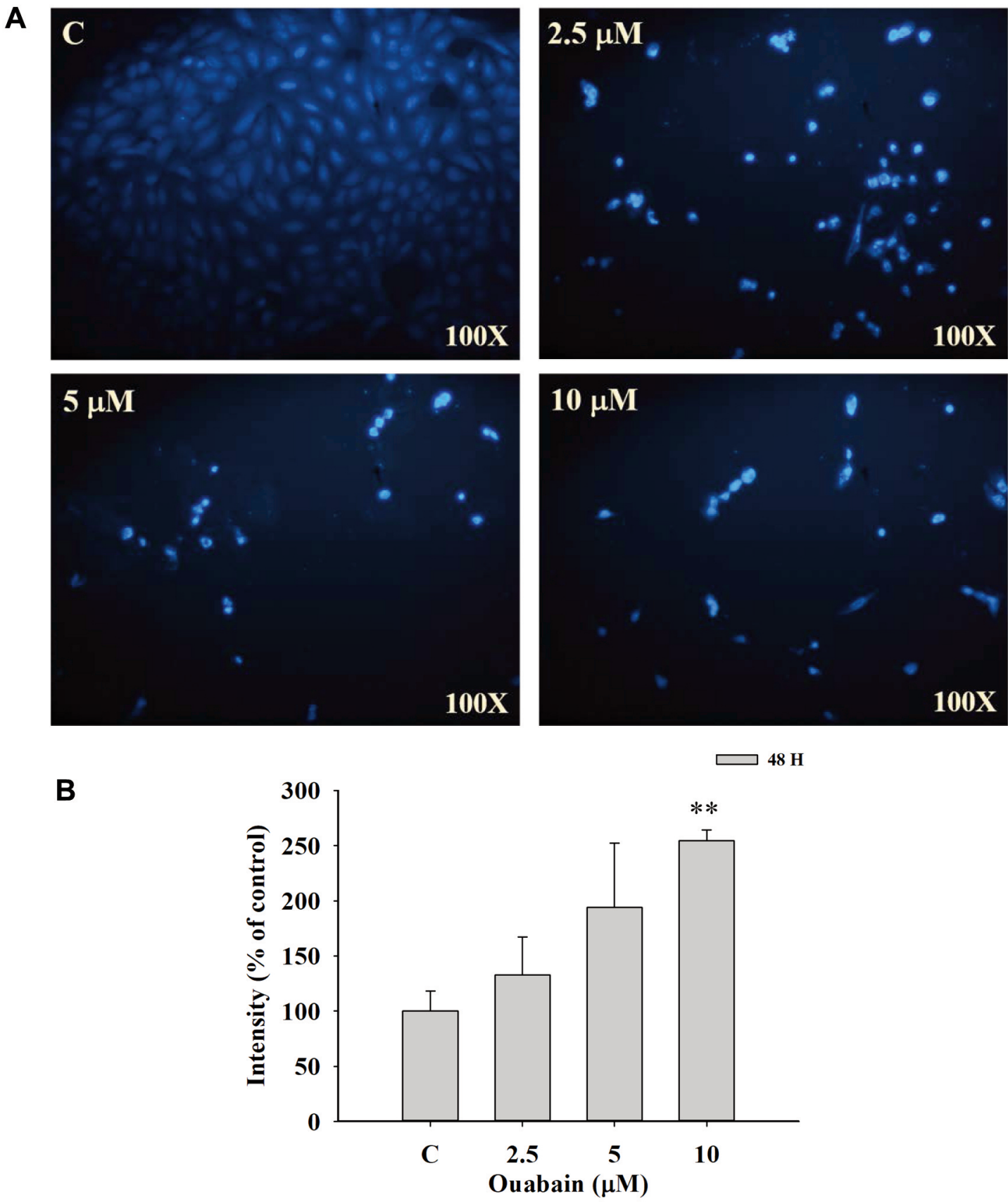

Figure 2. Ouabain affected DNA condensation in U-2 OS cells. Cells $\left(1.6 \times 10^{5}\right.$ cells/well $)$ were placed in 12-well plates and incubated with 0, 2.5, 5 , and $10 \mu \mathrm{M}$ of ouabain for $48 \mathrm{~h}$. Cells were fixed, permeablized and nuclei were stained with $2 \mu \mathrm{g} / \mathrm{ml}$ of DAPI for 10 min. All samples were examined and photographed using a fluorescence microscope at 100x (A) and were measured for the intensity of fluorescence $(B)$ as described in Materials and Methods. Data represent mean $\pm S . D .{ }^{*} p<0.05$ was significantly different between ouabain-treated and control groups.

Ouabain induced DNA fragmentation. To confirm the effects of ouabain on DNA damage, DNA fragmentation was analyzed by agarose gel electrophoresis, which displayed the presence of laddered DNA in U-2 OS cells. After exposure to $0,2.5,5$, and $10 \mu \mathrm{M}$ of ouabain for 48 h, DNA was extracted from each treatment and electrophoresed in agarose gel. As shown in Figure 4, ouabain induced DNA fragmentation at $48 \mathrm{~h}$ treatment, indicating the development of apoptotic cell death in U-2 OS cells. 
A
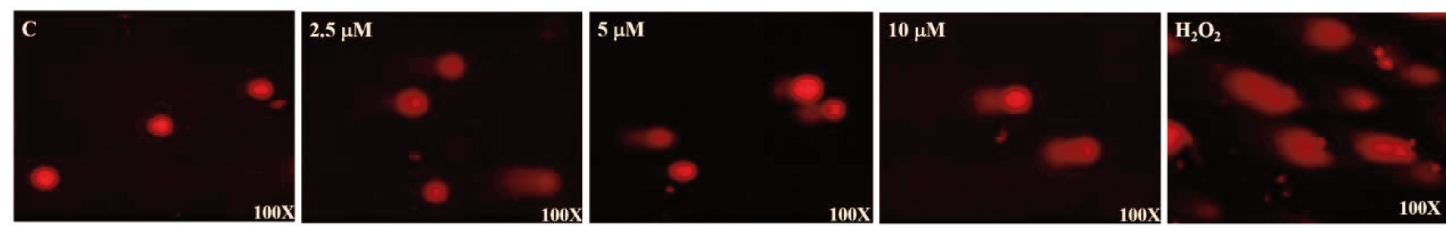

B

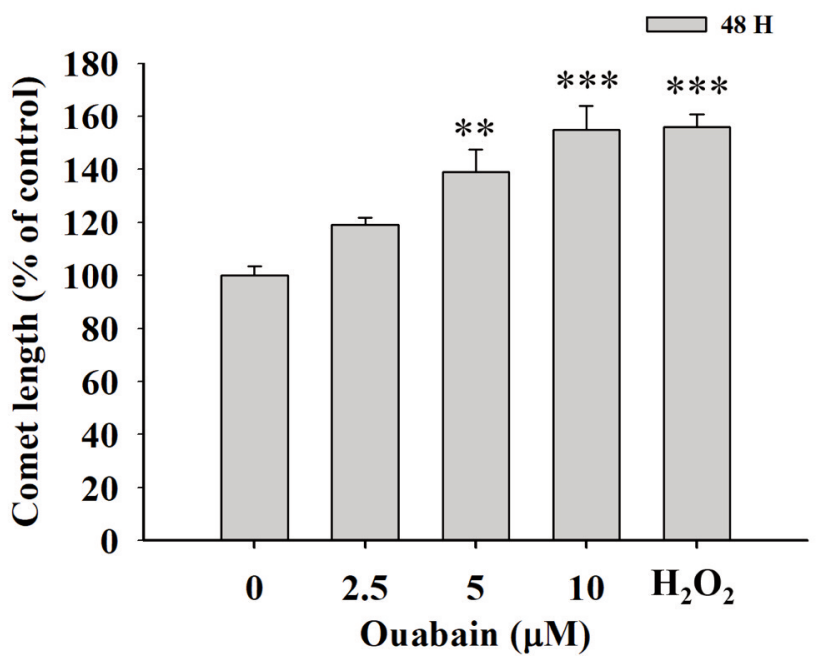

Figure 3. Ouabain induced DNA damage in U-2 OS cells. Cells were incubated with 0, 2.5, 5, and $10 \mu \mathrm{M}$ of ouabain and $\mathrm{H}_{2} \mathrm{O}_{2}$ for 48 h and were measured by the Comet assay (A) and evaluated for intensity of fluorescence (B) as described in Materials and Methods. Data represent mean $\pm S . D$. ${ }^{*} p<0.05$ was significantly different between ouabain-treated and control groups.

Ouabain affected the levels of DNA damage and repairassociated proteins. To further confirm ouabain altered DNA damage and repair-associated proteins, cells were exposed to $0,2.5,5$, and $10 \mu \mathrm{M}$ of ouabain for $48 \mathrm{~h}$ and collected for western blotting analysis. As shown in Figure 5, ouabain increased p-ATM ${ }^{\text {Ser1981 }}$, p-ATR ${ }^{\text {Ser428 }}$, and p53 at 2.5-10 $\mu \mathrm{M}$ and increased p-p53 $3^{\text {Ser15 }}$ at $10 \mu \mathrm{M}$. However, ouabain decreased p-MDM2 $2^{\operatorname{Ser} 166}$ at 2.5-10 $\mu \mathrm{M}$ (Figure 5A). Furthermore, ouabain increased p-H2A.X ${ }^{\text {Ser139 }}$, MDC-1, and PARP at 2.5-10 $\mu \mathrm{M}$, and increased BRCA1 at 5-10 $\mu \mathrm{M}$, but decreased DNA-PK and MGMT at 2.5-10 $\mu \mathrm{M}$ in U-2 OS cells at $48 \mathrm{~h}$ treatment (Figure 5B).

Ouabain affected nuclear translocation of p-H2A.X Ser139. Results from western blotting already showed that ouabain at 2.5-10 $\mu \mathrm{M}$ treatment increased $\mathrm{p}-\mathrm{H} 2 \mathrm{~A} . \mathrm{X}^{\mathrm{Ser} 139}$ protein levels in U-2 OS cells. We further investigated whether the induction of DNA damage by ouabain is also involved in the nuclear translocation of p-H2A.X $\mathrm{X}^{\mathrm{Ser} 139}$ in U-2 OS cells. Cells were exposed to $0,2.5,5$, and $10 \mu \mathrm{M}$ of ouabain for $48 \mathrm{~h}$, probed with p-H2A.X ${ }^{\text {Ser139 }}$ antibody, and observed under confocal laser microscopy. As shown in Figure 6, ouabain promoted the expression and enhanced the nuclear translocation of $\mathrm{p}$ -

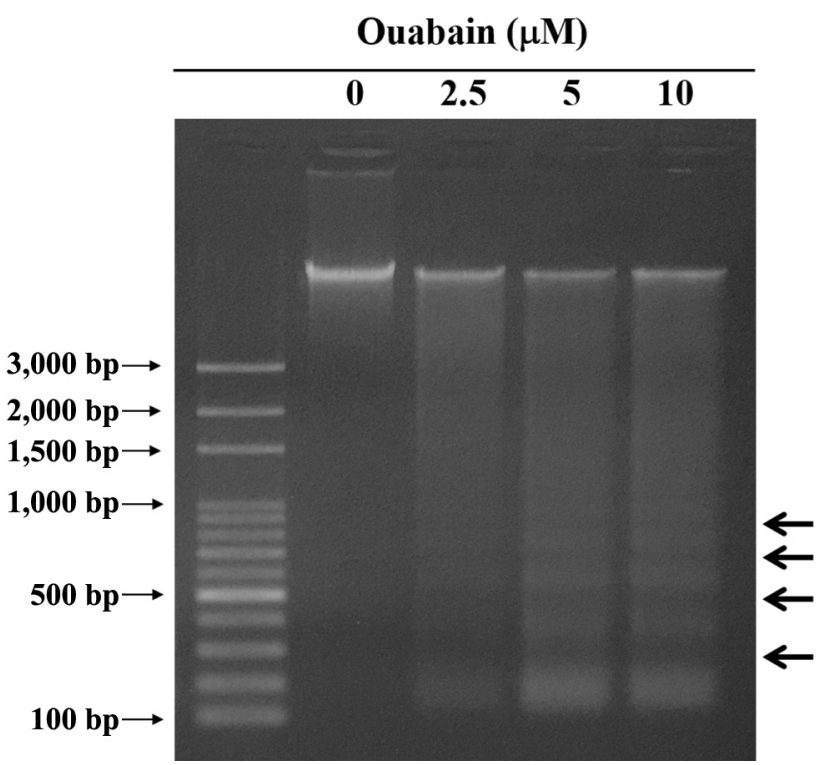

Figure 4. Ouabain induced DNA fragmentation in U-2 OS cells. Cells were incubated with 0, 2.5, 5, and $10 \mu \mathrm{M}$ of ouabain for $48 \mathrm{~h}$. Cells were collected, lysed and DNA was extracted for DNA gel electrophoresis as described in Materials and Methods. 
A

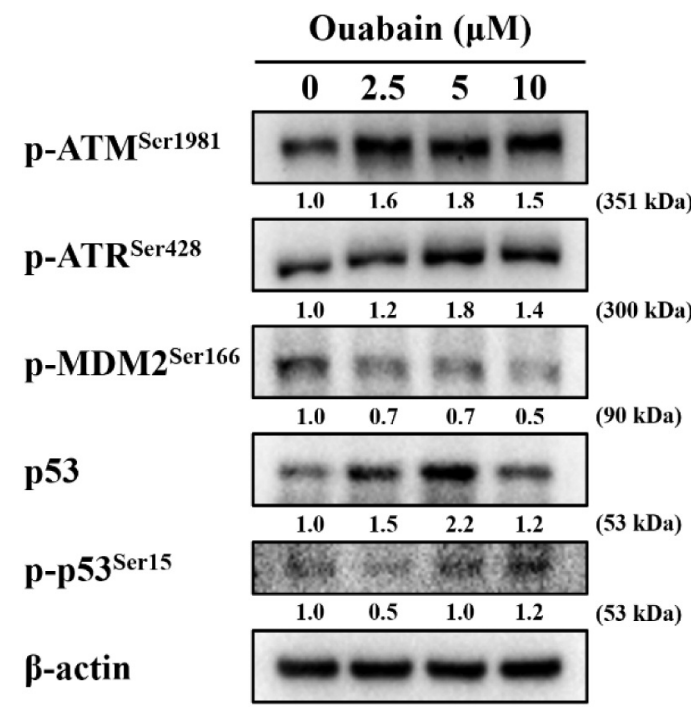

B

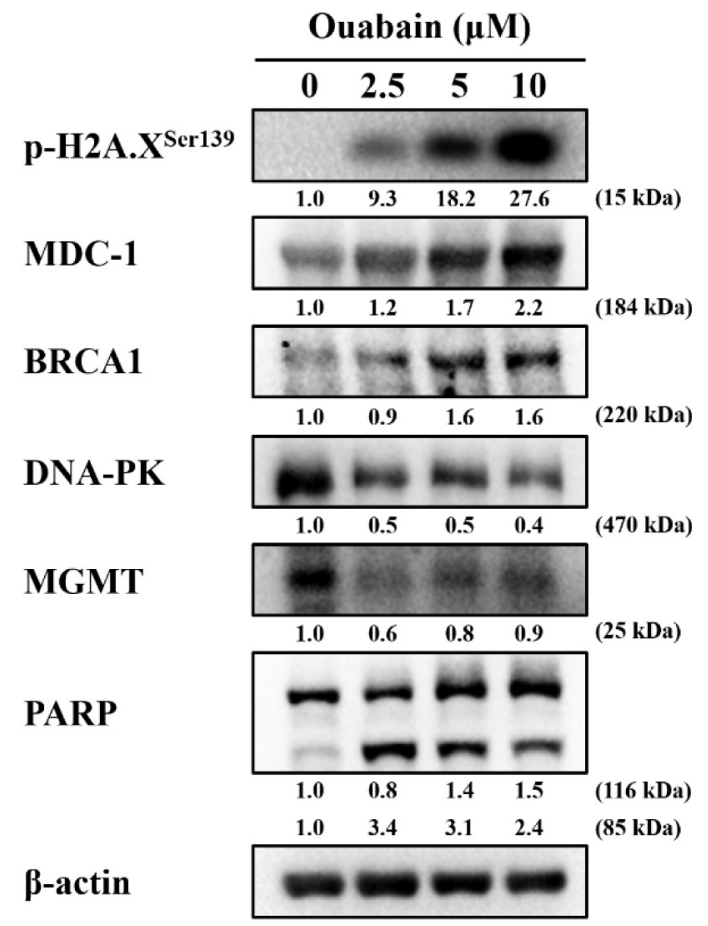

Figure 5. Ouabain altered the DNA damage and repair associated protein expressions in U-2 OS cells. Cells were placed in 10-cm dishes and were incubated with 0, 2.5, 5, and $10 \mu \mathrm{M}$ of ouabain for $48 \mathrm{~h}$. Cells were collected for western blotting and the resulting membranes were used to probe anti-p-ATMSer1981, - - $-A T R^{\operatorname{Ser} 428},-p-M D M 2^{S e r 166},-p 53$ and -p-p53Ser15 $(A),-p-H 2 A . X^{\operatorname{Ser} 139},-M D C 1,-B R C A 1,-D N A-P K,-M G M T$ and -PARP (B) as described in Materials and Methods. $\beta$-actin was used as an internal control.

H2A.X $\mathrm{X}^{\mathrm{Ser} 139}$ in U-2 OS cells and these effects were dosedependent (Figure 6).

\section{Discussion}

Numerous evidence has shown that certain clinical anticancer drugs not only induce cancer cell apoptosis but also cause DNA damage and alter the expression of DNA repair associated proteins. After further animal studies, anticancer drugs also reduced the tumor size of a tumorxenografted animal model in vivo (38-40). Furthermore, DNA damage is a critical parameter for examining the carcinogenicity of chemicals $(41,42)$. Numerous studies have shown that ouabain induced cytotoxic effects such as reducing total viable cell number in vitro and inducing cell apoptosis in vitro. Therefore, in the present study, the aim was to further investigate whether or not ouabain induces DNA damage in human osteosarcoma U-2 OS cells in vitro.

In the first experiments, we evaluated the cytotoxic effects of ouabain on U-2 OS cells and results indicated that ouabain reduced total cell viability dose-dependently (Figure 1). These results are also consistent with the report that ouabain decreased the total viable numbers of breast cancer cells (28). Our earlier studies have shown that ouabain reduced viable cell numbers via apoptotic cell death in U-2 OS cells (43). However, no report is available on whether ouabain reduces cell viability concerning DNA damage; therefore, we used DAPI staining, comet assay, and DNA electrophoresis to confirm these. As shown in Figure 2, ouabain induced DNA condensation timedependently. Many reports have shown that anticancer drugs induce DNA condensation (one of the aspects of cell apoptosis) in cancer cells, which were also able to be approved by DAPI staining $(44,45)$. Figure $3 \mathrm{~A}$ and B indicate that ouabain induced the development of DNA comet tailing, indicating DNA damage in U-2 OS cells. Cells exposed to genotoxic agents may have induced error replications of genomic DNA resulting in genomic instability and cancer development (15). The plasticity of chromatin structure provides cellular responses to DNA damage $(46,47)$ and chromosome is also the physiological template for DNA repair machinery to maintain and restore genome integrity for cell survival (36). Furthermore, DNA damage induced by ouabain in U-2 OS cells was observed in agarose gels, showing the presence of DNA fragmentation (laddered DNA), which is a marker of cell apoptosis $(15,48)$. 


\section{Ouabain $(\mu \mathrm{M})$}

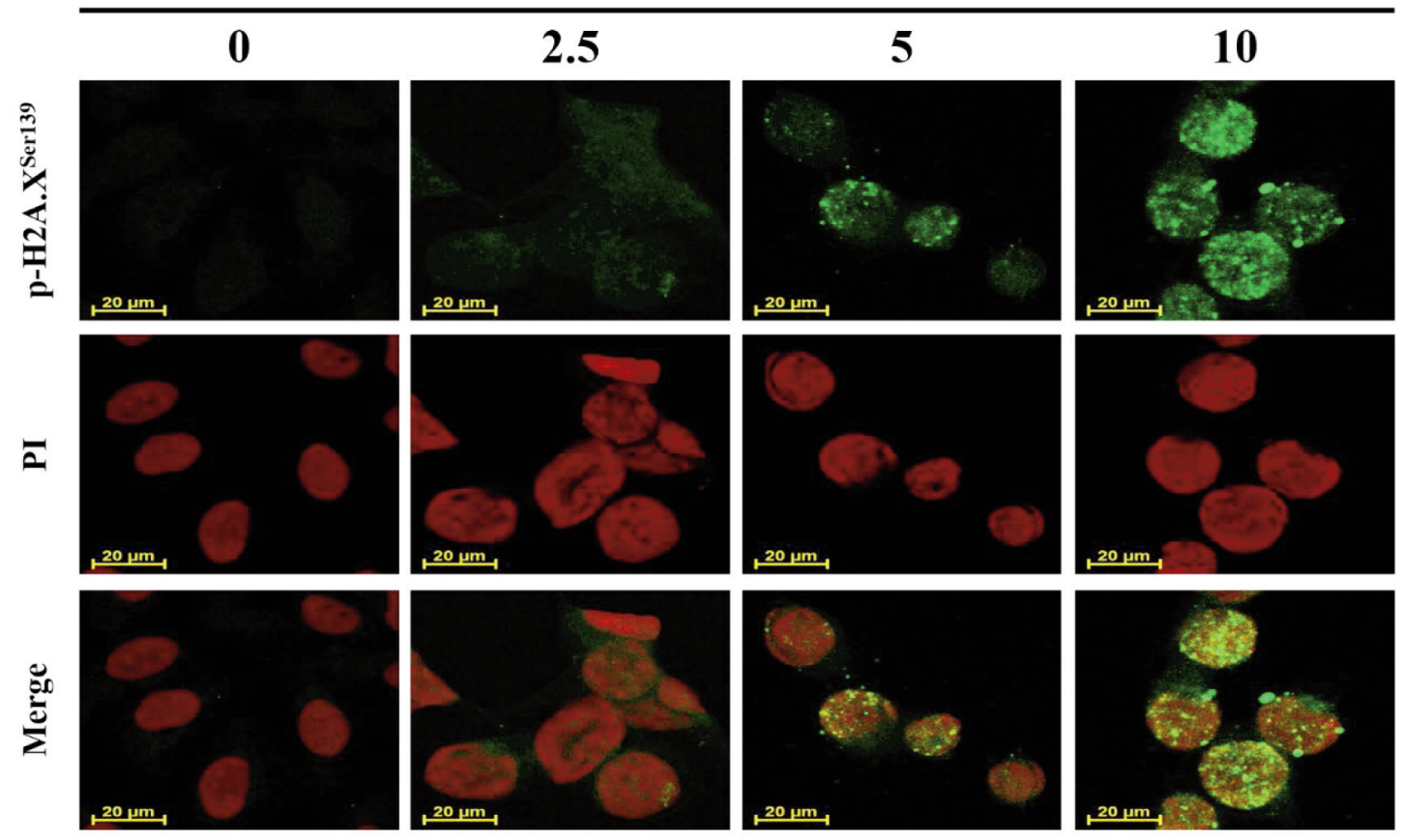

Figure 6. Ouabain altered the translocation of p-H2A.XSer139 in U-2 OS cells. Cells $\left(5 \times 10^{4}\right.$ cells/well) were placed on 4-well chamber slides and incubated with $0,2.5,5$, and $10 \mu \mathrm{M}$ of ouabain for $48 \mathrm{~h}$. Cells were stained by anti-p-H2A.XSer139 (green fluorescence) and were stained with FITC-conjugated goat anti-mouse IgG. All cells were stained by PI (red fluorescence) for nucleus examination and were photographed under a Leica TCS SP2 Confocal Spectral Microscope as described in Materials and Methods.

In the other parts of the experiment, we evaluated the expression of proteins associated with DNA damage and repair in U-2 OS cells after exposure to various concentrations of ouabain by western blotting. Results from Figure 5A indicated that ouabain increased phospho-ataxia telangiectasia mutation (p-ATM ${ }^{\text {Ser1981}}$ ), phosphor-ataxia telangiectasia and rad3-related (p-ATR $\left.{ }^{\mathrm{Ser} 428}\right), \mathrm{p} 53$, and $\mathrm{p}$ $\mathrm{p} 53^{\mathrm{Ser} 15}$ but decreased $\mathrm{p}-\mathrm{MDM} 2^{\mathrm{Ser} 166}$. It was reported that anticancer drugs such as etoposide could induce DNA double-strand breaks (DSBs), which can further activate ATM and ATR and then led to activating their target proteins, CHKs and p53, by phosphorylation to repair DSBs. If its DSB repair fails, cells will develop apoptosis $(11,49$, 50). Furthermore, if cells are exposed to genotoxic agents (or anticancer drugs) and result in DNA damage, ATM could phosphorylate p53 to stabilize and transactivate the p53 target genes for cell surviving; otherwise, cell would die (51). It was reported that the lack of ATM is involved in lymphoid malignancies in human and mice $(52,53)$.

Herein, ouabain significantly increased the expression of p$\mathrm{p} 3^{\mathrm{Ser} 15}$ at 2.5-5 $\mu \mathrm{M}$ (Figure 5A). p53 maintains genomic stability when stress occurs, including hypoxia, DNA damage, and oncogene activation (54). After the signals of stress activate p53 via post-transcriptional mechanisms, p53 is phosphorylated to form p-p53 (55). Our results also indicate that ouabain suppress the expression of $\mathrm{p}-\mathrm{MDM} 22^{\mathrm{Ser} 166}$ in U2 OS cells (Figure 5A). Recently, the mouse double minute 2 (MDM2) oncogene has been attractive for cancer therapy and the anti-MDM2 antisense oligo would be indicated as cancer therapeutic agents in the future (56).

Ouabain increased p-H2A.X. $\mathrm{X}^{\mathrm{Ser} 139}$, MDC-1, and PARP at 2.5-10 $\mu \mathrm{M}$ and BRCA1 at 5-10 $\mu \mathrm{M}$; however, it decreased DNA-PK and MGMT at 2.5-10 $\mu \mathrm{M}$ in U-2 OS cells at $48 \mathrm{~h}$ treatment (Figure 5B). It is reported that the phosphorylation of H2A.X (p-H2A.X ${ }^{\text {Ser139}}$ ) is a highly specific and sensitive molecular marker for DNA damage (57). Thus, in the present study, ouabain promoted the levels of p-ATM ${ }^{\text {Ser1981 }}$ and pp53 $3^{\text {Ser15 }}$ (Figure 5A) and increased p-H2A.X $\mathrm{X}^{\text {Ser139 }}$ (Figure $5 \mathrm{~B})$. That is in agreement with other reports that the activated ATM possesses kinase activity, which could phosphorylate its substrates, including p53 and histone H2A.X (58). Breast Cancer 1 (BRCA1) is associated with an increased risk of breast and ovarian cancer, and its expression regulates the response to cancer therapies (59). BRCA1 protein has been reported to directly participate in double-strand DNA (dsDNA) break repair (60). DNA breaks phosphorylate substrates to activate ATM, ATR, and DNA-PK, which jointly orchestrate DNA repair and cell recovery (61). Poly-ADP 


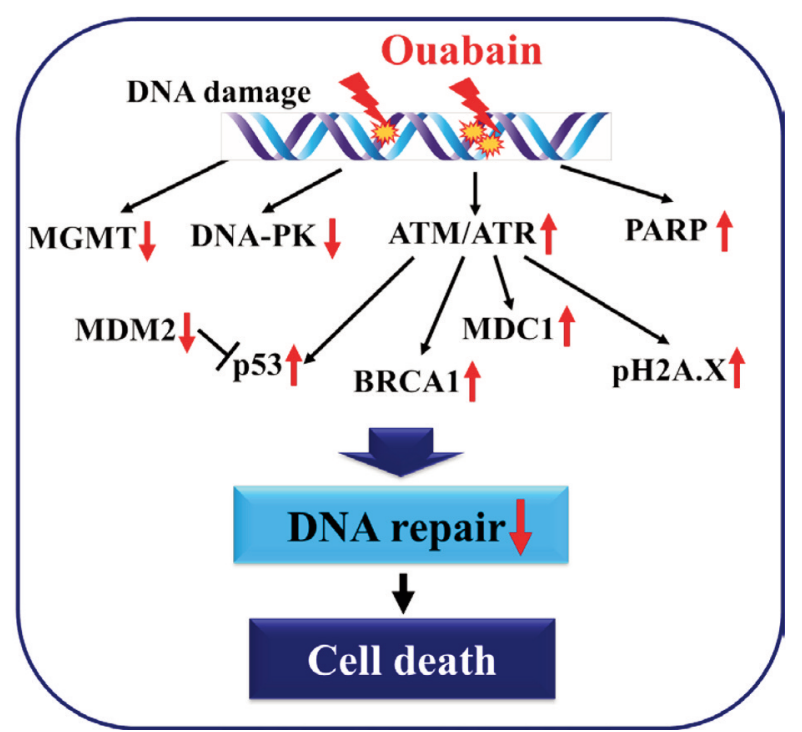

Figure 7. The possible signaling pathways for ouabain-induced DNA damage and repair in U-2 OS cells in vitro.

ribose polymerase (PARP) is involved in the DNA damage and repair system and in maintaining genome stability. Three related protein kinases, ataxia-telangiectasia mutated (ATM), ATM and Rad3-related (ATR), and DNA-dependent protein kinase (DNA-PK), are involved in the cellular response to DSBs (62). When DNA damage occurs, H2A.X, one the substrates of kinases, is phosphorylated on Ser139 at DSB sites and then referred to as $\gamma \mathrm{H} 2 \mathrm{~A} . \mathrm{X}$ (63) which is recognized by the mediator of DNA damage checkpoint 1 (MDC-1) (64) which acts as a platform for recruitment of various DNA damage response factors to mediate DNA repair.

In conclusion, based on these findings and observations, we suggested that ouabain decreased the total viable cell number of U-2 OS cells in vitro via induction of DNA damage and alteration of expression of DNA repair associated proteins. These results were also consistent with the results from the comet assay and DAPI staining, and were furthermore also confirmed ouabain-affected expression of DNA damage repair associated proteins such as p-ATM, p-ATR, BRCA1, MDC-1, p-H2A.X, p-p53, and MGMT in U-2 OS cells in vitro (Figure 7).

\section{Conflicts of Interest}

The Authors confirm that there are no conflicts of interest.

\section{Authors' Contributions}

Study conception and design: JLY, and MDY; Acquisition of data: JCC, KWL, YPH, and SFP; Analysis and interpretation of data:
FSC, KCL, and TSL; Drafting of manuscript: PYC, and WJC; Critical revision: PYC, and WJC. All Authors discussed the results and commented on the article.

\section{Acknowledgements}

This work was supported by Grant RD106060 from Chang Bing Show Chwan Memorial Hospital, Changhua, Taiwan, and by grant CMU109-ASIA-16 from China Medical University, Taichung, Taiwan. Experiments and data analysis were performed, in part, through the use of the Medical Research Core Facilities Center, Office of Research \& Development at China Medical University, Taichung, Taiwan.

\section{References}

1 Bielack SS, Kempf-Bielack B, Delling G, Exner GU, Flege S, Helmke K, Kotz R, Salzer-Kuntschik M, Werner M, Winkelmann W, Zoubek A, Jürgens H and Winkler K: Prognostic factors in high-grade osteosarcoma of the extremities or trunk: an analysis of 1,702 patients treated on neoadjuvant cooperative osteosarcoma study group protocols. J Clin Oncol 20(3): 776-790, 2002. PMID: 11821461. DOI: $10.1200 / J C O .2002 .20 .3 .776$

2 Mirabello L, Troisi RJ and Savage SA: Osteosarcoma incidence and survival rates from 1973 to 2004: data from the Surveillance, Epidemiology, and End Results Program. Cancer 115(7): 15311543, 2009. PMID: 19197972. DOI: 10.1002/cncr.24121

3 Finkel MP, Reilly CA Jr and Biskis BO: Pathogenesis of radiation and virus-induced bone tumors. Recent Results Cancer Res (54): 92-103, 1976. PMID: 189372. DOI: 10.1007/978-3-642-80997-2_7

4 Li X, Liu X, Fang J, Li H and Chen J: microRNA-363 plays a tumor suppressive role in osteosarcoma by directly targeting MAP2K4. Int J Clin Exp Med 8(11): 20157-20167, 2015. PMID: 26884928.

5 Hansen MF, Seton M and Merchant A: Osteosarcoma in Paget's disease of bone. J Bone Miner Res 21 Suppl 2: P58-P63, 2006. PMID: 17229010. DOI: 10.1359/jbmr.06s211

6 Ottaviani G and Jaffe N: The etiology of osteosarcoma. Cancer Treat Res 152: 15-32, 2009. PMID: 20213384. DOI: 10.1007/978-1-4419-0284-9_2

7 Ferrari S, Smeland S, Mercuri M, Bertoni F, Longhi A, Ruggieri P, Alvegard TA, Picci P, Capanna R, Bernini G, Müller C, Tienghi A, Wiebe T, Comandone A, Böhling T, Del Prever AB, Brosjö O, Bacci G, Saeter G and Italian and Scandinavian Sarcoma Groups: Neoadjuvant chemotherapy with high-dose Ifosfamide, high-dose methotrexate, cisplatin, and doxorubicin for patients with localized osteosarcoma of the extremity: a joint study by the Italian and Scandinavian Sarcoma Groups. J Clin Oncol 23(34): 8845-8852, 2005. PMID: 16246977. DOI: 10.1200/JCO.2004.00.5785

8 Jemal A, Siegel R, Ward E, Hao Y, Xu J, Murray T and Thun MJ: Cancer statistics, 2008. CA Cancer J Clin 58(2): 71-96, 2008. PMID: 18287387 . DOI: $10.3322 / C A .2007 .0010$

9 Ottaviani G and Jaffe N: The epidemiology of osteosarcoma. Cancer Treat Res 152: 3-13, 2009. PMID: 20213383. DOI: 10.1007/978-1-4419-0284-9_1

10 Han G, Wang Y, Bi W, Jia J and Wang W: MicroRNA-124 functions as a tumor suppressor and indicates prognosis in human osteosarcoma. Exp Ther Med 9(3): 679-684, 2015. PMID: 25667613. DOI: 10.3892/etm.2014.2161 
11 Schonn I, Hennesen J and Dartsch DC: Cellular responses to etoposide: cell death despite cell cycle arrest and repair of DNA damage. Apoptosis 15(2): 162-172, 2010. PMID: 20041303. DOI: $10.1007 / \mathrm{s} 10495-009-0440-9$

12 Stupp R, Mason WP, van den Bent MJ, Weller M, Fisher B, Taphoorn MJ, Belanger K, Brandes AA, Marosi C, Bogdahn U, Curschmann J, Janzer RC, Ludwin SK, Gorlia T, Allgeier A, Lacombe D, Cairncross JG, Eisenhauer E, Mirimanoff RO, European Organisation for Research and Treatment of Cancer Brain Tumor and Radiotherapy Groups and National Cancer Institute of Canada Clinical Trials Group: Radiotherapy plus concomitant and adjuvant temozolomide for glioblastoma. N Engl J Med 352(10): 987-996, 2005. PMID: 15758009. DOI: 10.1056/NEJMoa043330

13 Kaina B, Christmann M, Naumann S and Roos WP: MGMT: key node in the battle against genotoxicity, carcinogenicity and apoptosis induced by alkylating agents. DNA Repair (Amst) 6(8): 1079-1099, 2007. PMID: 17485253 . DOI: 10.1016/j.dnarep.2007.03.008

14 Zhao H, Albino AP, Jorgensen E, Traganos F and Darzynkiewicz $\mathrm{Z}$ : DNA damage response induced by tobacco smoke in normal human bronchial epithelial and A549 pulmonary adenocarcinoma cells assessed by laser scanning cytometry. Cytometry A 75(10): 840-847, 2009. PMID: 19658174. DOI: 10.1002/cyto.a.20778

15 Ciccia A and Elledge SJ: The DNA damage response: making it safe to play with knives. Mol Cell 40(2): 179-204, 2010. PMID: 20965415. DOI: 10.1016/j.molcel.2010.09.019

16 Jackson SP and Bartek J: The DNA-damage response in human biology and disease. Nature 461(7267): 1071-1078, 2009. PMID: 19847258 . DOI: 10.1038 /nature08467

17 Smith J, Tho LM, Xu N and Gillespie DA: The ATM-Chk2 and ATR-Chk1 pathways in DNA damage signaling and cancer. Adv Cancer Res 108: 73-112, 2010. PMID: 21034966. DOI: 10.1016/B978-0-12-380888-2.00003-0

18 Schoner W, Bauer N, Müller-Ehmsen J, Krämer U, Hambarchian N, Schwinger R, Moeller H, Kost H, Weitkamp C, Schweitzer T, Kirch U, Neu H and Grünbaum EG: Ouabain as a mammalian hormone. Ann N Y Acad Sci 986: 678-684, 2003. PMID: 12763918. DOI: 10.1111/j.1749-6632.2003.tb07282.x

19 Schoner W and Scheiner-Bobis G: Endogenous cardiac glycosides: hormones using the sodium pump as signal transducer. Semin Nephrol 25(5): 343-351, 2005. PMID: 16139690. DOI: 10.1016/j.semnephrol.2005.03.010

20 Cereijido M, Contreras RG, Shoshani L and Larre I: The $\mathrm{Na}^{+-}$ $\mathrm{K}^{+}$-ATPase as self-adhesion molecule and hormone receptor. Am J Physiol Cell Physiol 302(3): C473-C481, 2012. PMID: 22049208. DOI: 10.1152/ajpcell.00083.2011

21 Nicholls MG, Lewis LK, Yandle TG, Lord G, McKinnon W and Hilton PJ: Ouabain, a circulating hormone secreted by the adrenals, is pivotal in cardiovascular disease. Fact or fantasy? J Hypertens 27(1): 3-8, 2009. PMID: 19050442. DOI: 10.1097/HJH.0b013e32831101d1

22 Zhang L, Zhang Z, Guo H and Wang Y: Na+/K+-ATPasemediated signal transduction and $\mathrm{Na}^{+} / \mathrm{K}^{+}$-ATPase regulation. Fundam Clin Pharmacol 22(6): 615-621, 2008. PMID: 19049666. DOI: $10.1111 / \mathrm{j} .1472-8206.2008 .00620 . x$

23 Nesher M, Dvela M, Igbokwe VU, Rosen H and Lichtstein D: Physiological roles of endogenous ouabain in normal rats. Am J Physiol Heart Circ Physiol 297(6): H2026-H2034, 2009. PMID: 19837951. DOI: 10.1152/ajpheart.00734.2009
24 Fedorova OV, Shapiro JI and Bagrov AY: Endogenous cardiotonic steroids and salt-sensitive hypertension. Biochim Biophys Acta 1802(12): 1230-1236, 2010. PMID: 20347967. DOI: $10.1016 /$ j.bbadis.2010.03.011

25 Prassas I and Diamandis EP: Novel therapeutic applications of cardiac glycosides. Nat Rev Drug Discov 7(11): 926-935, 2008. PMID: 18948999. DOI: $10.1038 / \mathrm{nrd} 2682$

26 Kong D, Li J, Zhao B, Xia B, Zhang L, He Y, Wang X, Gao L, Wang Y, Jin X and Lou G: The effect of SCF and ouabain on small intestinal motility dysfunction induced by gastric cancer peritoneal metastasis. Clin Exp Metastasis 32(3): 267-277, 2015. PMID: 25689893. DOI: 10.1007/s10585-015-9702-9

27 Newman RA, Yang P, Pawlus AD and Block KI: Cardiac glycosides as novel cancer therapeutic agents. Mol Interv 8(1): 36-49, 2008. PMID: 18332483. DOI: 10.1124/mi.8.1.8

28 Kobayakawa J, Sato-Nishimori F, Moriyasu M and Matsukawa Y: G2-M arrest and antimitotic activity mediated by casticin, a flavonoid isolated from Viticis Fructus (Vitex rotundifolia Linne fil.). Cancer Lett 208(1): 59-64, 2004. PMID: 15105046. DOI: 10.1016/j.canlet.2004.01.012

29 Chanvorachote $\mathrm{P}$ and Pongrakhananon V: Ouabain downregulates Mcl-1 and sensitizes lung cancer cells to TRAILinduced apoptosis. Am J Physiol Cell Physiol 304(3): C263C272, 2013. PMID: 23174563. DOI: 10.1152/ajpcell.00225.2012

30 Chang YM, Shih YL, Chen CP, Liu KL, Lee MH, Lee MZ, Hou HT, Huang HC, Lu HF, Peng SF, Chen KW, Yeh MY and Chung JG: Ouabain induces apoptotic cell death in human prostate DU 145 cancer cells through DNA damage and TRAIL pathways. Environ Toxicol 34(12): 1329-1339, 2019. PMID: 31436044. DOI: $10.1002 /$ tox. 22834

31 Tang SY, Zhong MZ, Yuan GJ, Hou SP, Yin LL, Jiang H and Yu ZY: Casticin, a flavonoid, potentiates TRAIL-induced apoptosis through modulation of anti-apoptotic proteins and death receptor 5 in colon cancer cells. Oncol Rep 29(2): 474-480, 2013. PMID: 23135489. DOI: $10.3892 /$ or.2012.2127

32 Xiao Y, Meng C, Lin J, Huang C, Zhang X, Long Y, Huang Y and Lin Y: Ouabain targets the $\mathrm{Na}^{+} / \mathrm{K}^{+}$-ATPase $\alpha_{3}$ isoform to inhibit cancer cell proliferation and induce apoptosis. Oncol Lett 14(6): 6678-6684, 2017. PMID: 29163695. DOI: $10.3892 / \mathrm{ol} .2017 .7070$

33 da Silva JMC, Azevedo ADN, Barbosa RPDS, Teixeira MP, Vianna TAG, Fittipaldi J, Cabral VR and Paiva LS: Ouabain Decreases Regulatory T Cell Number in Mice by Reducing IL2 Secretion. Neuroimmunomodulation 26(4): 188-197, 2019. PMID: 31412342. DOI: 10.1159/000501720

34 Chueh FS, Chen YY, Huang AC, Ho HC, Liao CL, Yang JS, Kuo CL and Chung JG: Bufalin-inhibited migration and invasion in human osteosarcoma U-2 OS cells is carried out by suppression of the matrix metalloproteinase-2, ERK, and JNK signaling pathways. Environ Toxicol 29(1): 21-29, 2014. PMID: 21922632. DOI: 10.1002/tox.20769

35 Lee CF, Chiang NN, Lu YH, Huang YS, Yang JS, Tsai SC, Lu $\mathrm{CC}$ and Chen FA: Benzyl isothiocyanate (BITC) triggers mitochondria-mediated apoptotic machinery in human cisplatinresistant oral cancer CAR cells. Biomedicine (Taipei) 8(3): 15, 2018. PMID: 30141402. DOI: 10.1051/bmdcn/2018080315

36 Shih YL, Chou J, Yeh MY, Chou HM, Chou HC, Lu HF, Shang HS, Chueh FS, Chu YL, Hsueh SC and Chung JG: Casticin induces DNA damage and inhibits DNA repair-associated protein expression in B16F10 mouse melanoma cancer cells. 
Oncol Rep 36(4): 2094-2100, 2016. PMID: 27572101. DOI 10.3892/or.2016.5027

37 Kuo JH, Shih TY, Lin JP, Lai KC, Lin ML, Yang MD and Chung JG: Cantharidin induces DNA damage and inhibits DNA repairassociated protein expressions in TSGH8301 human bladder cancer cell. Anticancer Res 35(2): 795-804, 2015. PMID: 25667459.

38 McCloskey DE, Kaufmann SH, Prestigiacomo LJ and Davidson NE: Paclitaxel induces programmed cell death in MDA-MB-468 human breast cancer cells. Clin Cancer Res 2(5): 847-854, 1996. PMID: 9816240.

39 Hu L, Hofmann J, Lu Y, Mills GB and Jaffe RB: Inhibition of phosphatidylinositol 3'-kinase increases efficacy of paclitaxel in in vitro and in vivo ovarian cancer models. Cancer Res 62(4): 1087-1092, 2002. PMID: 11861387.

40 Hentze H, Latta M, Künstle G, Dhakshinamoorthy S, Ng PY, Porter AG and Wendel A: Topoisomerase inhibitor camptothecin sensitizes mouse hepatocytes in vitro and in vivo to TNFmediated apoptosis. Hepatology 39(5): 1311-1320, 2004. PMID: 15122760. DOI: $10.1002 /$ hep. 20174

41 Nesnow S, Argus M, Bergman H, Chu K, Frith C, Helmes T, McGaughy R, Ray V, Slaga TJ and Tennant R: Chemical carcinogens. A review and analysis of the literature of selected chemicals and the establishment of the Gene-Tox Carcinogen Data Base. A report of the U.S. Environmental Protection Agency Gene-Tox Program. Mutat Res 185(1-2): 1-195, 1987. PMID: 3540654. DOI: 10.1016/0165-1110(87)90017-0

42 Barnes JL, Zubair M, John K, Poirier MC and Martin FL: Carcinogens and DNA damage. Biochem Soc Trans 46(5): 1213 1224, 2018. PMID: 30287511. DOI: 10.1042/BST20180519

43 Chou WH, Liu KL, Shih YL, Chuang YY, Chou J, Lu HF, Jair HW, Lee MZ, Au MK and Chung JG: Ouabain induces apoptotic cell death through caspase- and mitochondria-dependent pathways in human osteosarcoma U-2 OS cells. Anticancer Res 38(1): 169178, 2018. PMID: 29277770. DOI: 10.21873/anticanres.12205

44 Yang MY, Wang CJ, Chen NF, Ho WH, Lu FJ and Tseng TH: Luteolin enhances paclitaxel-induced apoptosis in human breast cancer MDA-MB-231 cells by blocking STAT3. Chem Biol Interact 213: 60-68, 2014. PMID: 24525192. DOI: 10.1016/j.cbi.2014.02.002

45 Jakubowska J, Stasiak M, Szulawska A, Bednarek A and Czyz M: Combined effects of doxorubicin and STI571 on growth, differentiation and apoptosis of CML cell line K562. Acta Biochim Pol 54(4): 839-846, 2007. PMID: 17957275.

46 Soria G, Polo SE and Almouzni G: Prime, repair, restore: the active role of chromatin in the DNA damage response. Mol Cell 46(6): 722-734, 2012. PMID: 22749398. DOI: 10.1016/ j.molcel.2012.06.002

47 Papamichos-Chronakis M and Peterson CL: Chromatin and the genome integrity network. Nat Rev Genet 14(1): 62-75, 2013. PMID: 23247436. DOI: 10.1038/nrg3345

$48 \mathrm{Wu}$ LY, Lu HF, Chou YC, Shih YL, Bau DT, Chen JC, Hsu SC and Chung JG: Kaempferol induces DNA damage and inhibits DNA repair associated protein expressions in human promyelocytic leukemia HL-60 cells. Am J Chin Med 43(2): 365-382, 2015. PMID: 25779644. DOI: 10.1142/S0192415X1550024X

49 De Zio D, Cianfanelli V and Cecconi F: New insights into the link between DNA damage and apoptosis. Antioxid Redox Signal 19(6): 559-571, 2013. PMID: 23025416. DOI: 10.1089/ars.2012.4938

50 Norbury CJ and Zhivotovsky B: DNA damage-induced apoptosis. Oncogene 23(16): 2797-2808, 2004. PMID: 15077143. DOI: $10.1038 /$ sj.onc.1207532
51 Cheng Q and Chen J: Mechanism of p53 stabilization by ATM after DNA damage. Cell Cycle 9(3): 472-478, 2010. PMID: 20081365. DOI: $10.4161 / \mathrm{cc} .9 .3 .10556$

52 Taylor AM, Metcalfe JA, Thick J and Mak YF: Leukemia and lymphoma in ataxia telangiectasia. Blood 87(2): 423-438, 1996. PMID: 8555463.

53 Barlow C, Hirotsune S, Paylor R, Liyanage M, Eckhaus M, Collins F, Shiloh Y, Crawley JN, Ried T, Tagle D and WynshawBoris A: Atm-deficient mice: a paradigm of ataxia telangiectasia. Cell 86(1): 159-171, 1996. PMID: 8689683. DOI: 10.1016/ s0092-8674(00)80086-0

54 Vogelstein B, Lane D and Levine AJ: Surfing the p53 network. Nature 408(6810): 307-310, 2000. PMID: 11099028. DOI: $10.1038 / 35042675$

55 Giaccia AJ and Kastan MB: The complexity of p53 modulation: emerging patterns from divergent signals. Genes Dev 12(19): 2973-2983, 1998. PMID: 9765199. DOI: 10.1101/gad.12.19.2973

56 Wang H, Nan L, Yu D, Agrawal S and Zhang R: Antisense antiMDM2 oligonucleotides as a novel therapeutic approach to human breast cancer: in vitro and in vivo activities and mechanisms. Clin Cancer Res 7(11): 3613-3624, 2001. PMID: 11705884.

57 Mah LJ, El-Osta A and Karagiannis TC: gammaH2AX: a sensitive molecular marker of DNA damage and repair. Leukemia 24(4): 679-686, 2010. PMID: 20130602. DOI: 10.1038/leu.2010.6

58 Friedberg EC: DNA damage and repair. Nature 421(6921): 436440, 2003. PMID: 12540918. DOI: 10.1038/nature01408

59 Krieger KL, Hu WF, Ripperger T and Woods NT: Functional impacts of the BRCA1-mTORC2 interaction in breast cancer. Int J Mol Sci 20(23): 5876, 2019. PMID: 31771139. DOI: 10.3390/ijms20235876

60 Takaoka M and Miki Y: BRCA1 gene: function and deficiency. Int J Clin Oncol 23(1): 36-44, 2018. PMID: 28884397. DOI: 10.1007/s10147-017-1182-2

61 Shiloh Y and Ziv Y: The ATM protein kinase: regulating the cellular response to genotoxic stress, and more. Nat Rev Mol Cell Biol 14(4): 197-210, 2013. PMID: 23847781.

62 Blackford AN and Jackson SP: ATM, ATR, and DNA-PK: The Trinity at the heart of the DNA damage response. Mol Cell 66(6): 801-817, 2017. PMID: 28622525. DOI: 10.1016/ j.molcel.2017.05.015

63 Rogakou EP, Boon C, Redon C and Bonner WM: Megabase chromatin domains involved in DNA double-strand breaks in vivo. J Cell Biol 146(5): 905-916, 1999. PMID: 10477747. DOI: 10.1083/jcb.146.5.905

64 Stucki M, Clapperton JA, Mohammad D, Yaffe MB, Smerdon SJ and Jackson SP: MDC1 directly binds phosphorylated histone $\mathrm{H} 2 \mathrm{AX}$ to regulate cellular responses to DNA double-strand breaks. Cell 123(7): 1213-1226, 2005. PMID: 16377563. DOI: 10.1016/j.cell.2005.09.038 